\title{
USABILITY ANALYSIS ON THE ENDANGERED INDONESIAN ANIMALS AND PLANTS AUGMENTED REALITY APPLICATION
}

\author{
Putri Syifa Darmawel \\ Master of Business Information Systems \\ Technology and Engineering Master Program \\ Gunadarma University \\ www.gunadarma.ac.id \\ putrisyifad@gmail.com
}

\begin{abstract}
Knowledge about Indonesian endangered animals and plants has been taught at elementary school, but still based on text. In curriculum 2013, teachers are expected to be able to develop creative ideas such as using interactive learning media that makes learning fun for students. Interactive learning media can be used as a solution to make the learning process more interesting. The use of augmented reality technology can be implemented on interactive learning media that aims to increase elementary school children's interest and make the learning process easier for the teacher. This research uses a descriptive quantitative method by distributing questionnaires to test the HEBULA Application which is an interactive learning media for introducing endangered Indonesian animals and plants using augmented reality technology for elementary school children. Testing is done by using the User Acceptance Test (UAT). This research aims to find out whether the HEBULA Application can be well received and effectively used as a learning media. The results of this research show that HEBULA Application is suitable to be used as a learning media which is shown by the percentage of UAT eligibility of $92,6 \%$ that can be categorized as very well.
\end{abstract}

Keywords : interactive learning media, augmented reality, endangered Indonesian animals and plants, user acceptance test

Abstrak- Pengetahuan tentang hewan dan tumbuhan langka di Indonesia diperkenalkan sejak berada di Sekolah Dasar (SD), namun pembelajaran masih terbatas teks. Pada Kurikulum 2013 guru diharapkan untuk mengembangkan ideide kreatif seperti menggunakan media pembelajaran interaktif yang dapat menarik minat belajar anak. Media pembelajaran interaktif dapat digunakan sebagai solusi untuk membuat proses pembelajaran menjadi lebih menarik. Penggunaan teknologi Augmented Reality dapat diimplementasikan pada media pembelajaran interaktif dengan harapan dapat meningkatkan minat belajar anak SD dan mempermudah guru dalam proses pembelajaran. Penelitian ini menggunakan metode kuantitatif deskriptif dengan menyebarkan kuesioner untuk melakukan uji coba pada Aplikasi HEBULA yang merupakan media pembelajaran interaktif dalam pengenalan hewan dan tumbuhan langka di Indonesia dengan menggunakan teknologi AR untuk anak SD. Pengujian yang dilakukan yaitu pengujian usability dengan menggunakan menggunakan User Acceptance Test (UAT). Hal ini dilakukan untuk mengetahui apakah Aplikasi HEBULA dapat diterima dengan baik dan efektif digunakan sebagai media pembelajaran. Hasil dari penelitian menunjukan bahwa Aplikasi HEBULA layak untuk dijadikan sebagai media pembelajaran yang ditunjukan oleh presentase kelayakan UAT sebesar $92,6 \%$ yang dapat dikategorikan dengan sangat baik.

Kata Kunci: media pembelajaran interaktif, augmented reality, hewan dan tumbuhan langka Indonesia, user acceptance test

\section{INTRODUCTION}

Knowledge about endangered animals and plants in Indonesia has been introduced from an early age, this can be seen from the existence of learning materials for the preservation of living things in schools, especially at the elementary school (Sembiring, Wahyuni, \& Anurogo, 2018). The introduction of endangered animals and plants in Indonesia to children aims to form the idea that endangered animals and plants need to be protected and preserved to avoid extinction. The learning method currently used is curriculum 2013. The curriculum 2013 for elementary school uses a thematic learning approach (Suraya, 2014). Teachers are expected to be able to develop further creative ideas by utilizing alternative activities offered in the teacher manual (Kemdikbud, 2017), or develop their learning ideas, such as interactive learning media where learning methods combine fun and learning (Irfansyah, 2017). The problem that often occurs now is the absence of media that can attract children and the use of pictorial paper 
media is not enough to stimulate their minds, feelings and, hearts (Hidayat \& Setiyadi, 2017).

Interactive multimedia is a media equipped with a controller that can be operated by the user, so that users can choose what they want (Wibowo, 2012) for the next process, such as interactive learning and game applications, while learning is defined as the process of creating an enabling environment (Sutisna \& Hikmah, 2018) the learning process occurs (Dewi, Isnanto, \& Martono, 2015). One of the objectives of learning with interactive multimedia is to replace and or complement and support the elements of objectives, materials, methods (Devayana, 2017), and assessment tools that exist in the teaching and learning process in conventional education systems that are commonly used (Dewi et al., 2015), (Lubis, Ritonga, Hia, \& Nasution, 2020). Learning using interactive multimedia can be a solution to increase children's interest in the learning process (Hamidi, 2018). In his research, the creation of interactive learning media for Islamic religious education was made to support the implementation of the curriculum 2013. In this research, it can be concluded that interactive learning media can support the implementation of the curriculum 2013 and is suitable for use as a learning resource for seventh-grade students.

Augmented Reality (AR) can be regarded as a technology that integrates computer-generated objects and virtual content into the real world, thereby it can improve (Kamphuis, Barsom, Schijven, \& Christoph, 2014) the perception of reality (Thomas, Linder, Harper, Blyth, \& Yee, 2019). This technology can make an object that is initially flat or two-dimensional (2D) as if it becomes real and blends with the surrounding environment. The use of AR technology can be utilized in the learning of endangered animals and plants at the elementary school which can be adjusted to the method in the curriculum 2013 learning. The advantages possessed by $A R$ are more interactive so that the application of the concepts used can increase one's reasoning power and imagination (Dhiyatmika, Putra, \& Mandenni, 2015). The creation of three-dimensional (3D) objects and their shapes which are the combination of real and virtual objects can increase children's interest in learning more about the material. The application of the AR concept to the learning method can create a more real learning atmosphere (Kamiana, Made, \& Gede, 2019).

Similar research was conducted on the analysis of the use of logical algebraic interactive learning media using the User Acceptance Test (UAT) (Agustina \& Suprianto, 2018). The results of this research, namely $86 \%$ of respondents stated that they agreed that interactive learning media were very useful and easy to use which were considered appropriate (Agustina \& Suprianto, 2018) with learning needs and were declared feasible to be developed again. Other research concerns interactive learning media using AR (Feoh \& Cristyadi, 2018). This research states that learning using AR is very feasible to be used in helping teachers explain and increase student interest. Based on the UAT test results obtained, the feasibility percentage was $88.74 \%$ which can be categorized as very good feasibility.

This research aims to analyze the use of the HEBULA Application which is a learning media for endangered animals and plants in Indonesia using Augmented Reality (AR) for elementary school children using usability testing. The method used is the User Acceptance Test (UAT). This is done to determine the benefits of implementing interactive learning media for elementary school children. Whether using this application can increase the effectiveness in the learning process and can be well received by users.

\section{MATERIALS AND METHODS}

The research flow can be seen in the diagram, as in Figure 1.

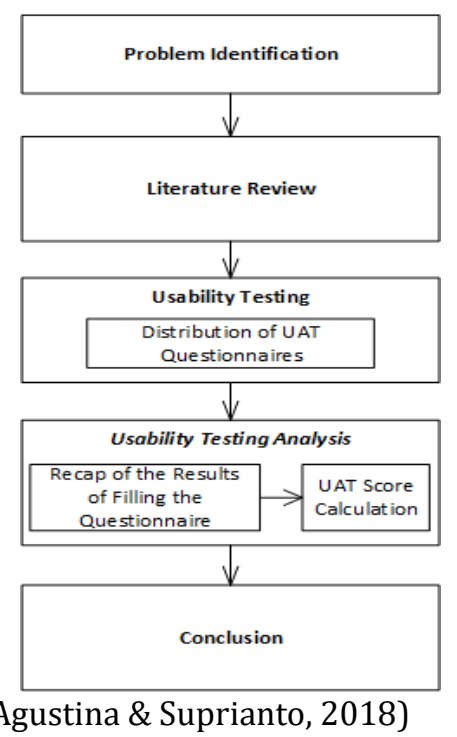

Figure 1. Research Framework

Figure 1. is the research framework. The first stage is the problem identification stage. The second stage is a literature review. The usability testing using the User Acceptance Test (UAT) method. At this stage, the researcher distributes questionnaires to target users. The next stage is usability testing analysis, which consists of a recap of the results of filling out the questionnaire and calculating UAT. After the results of the UAT are obtained, the final stage is to conclude the use of 
AR-based learning media for endangered animals and plants in Indonesia in elementary school children.

The data collection technique used in this research is descriptive quantitative. The data was collected by distributing questionnaires. The object of this research is the HEBULA Application which is an interactive learning media application about endangered animals and plants in Indonesia using AR which is focused on elementary school children.

The UAT test is based on two criteria. The aspects used are display and functional. The display aspect aims to determine whether the display of the application is by the purpose and can be attractive to the user, while the functional aspect aims to determine whether the application is running well and is useful for the user.

The questionnaire was distributed to ten respondents starting from grade first to sixth grade. The questionnaire consisted of ten statements consisting of five statements regarding display aspects and five statements regarding aspects of functional. The questionnaire was created using a Likert scale assessment consisting of five levels of assessment, namely Strongly Agree $(\mathrm{SA})$, Agree (A), Neutral (N), Disagree (D), and Strongly Disagree (SD) as well as in the Indonesian Language can be referred as Sangat Setuju (SS), Setuju (S), Netral (N), Tidak Setuju (TS), and Sangat Tidak Setuju (STS). Each assessment has a different weight.

From the results of this test, results will be obtained that can be used to analyze the suitability of the system that has been designed with user needs, especially in terms of display and functionality. This test will show whether the application can run well and the results of the level of user satisfaction with the application.

\section{RESULTS AND DISCUSSION}

\section{User Interface Design}

The display of the HEBULA Application can be seen in the following image:

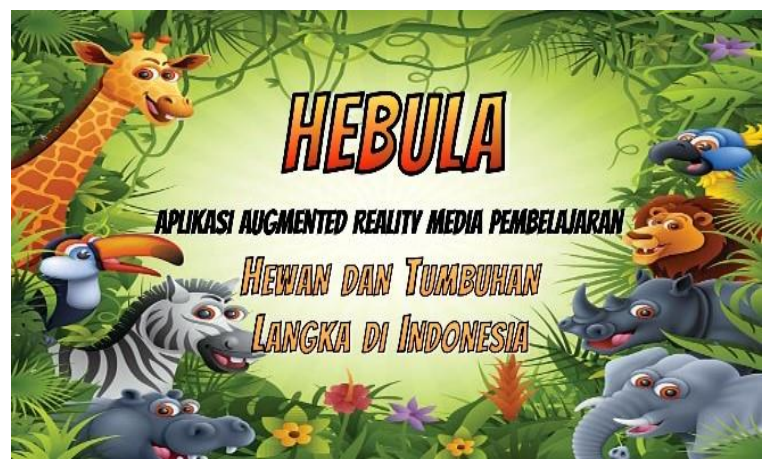

Source : (Darmawel, 2019)

Figure 2. Display of Splash Screen
Figure 2. is the display of the HEBULA splash screen. This display will appear when the user opens the Application. In the HEBULA splash screen, there is the name of the application that is 'HEBULA' which stands for 'Hewan dan Tumbuhan Langka Indonesia' which means Indonesian endangered animals and plants.

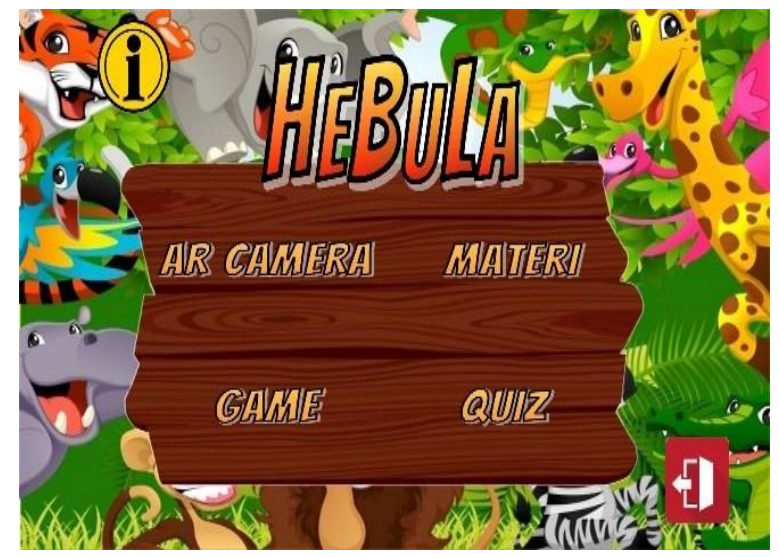

Source : (Darmawel, 2019)

Figure 3. Display of Main Menu

Figure 3. is the display of the main menu. There are four menus in this application consist of AR cameras, materials, games, and quiz. The button with the yellow ' $i$ ' symbol on the top left is a guide for using the AR camera, while the red button with the exit symbol on the bottom right is a button that allows users to exit the application.

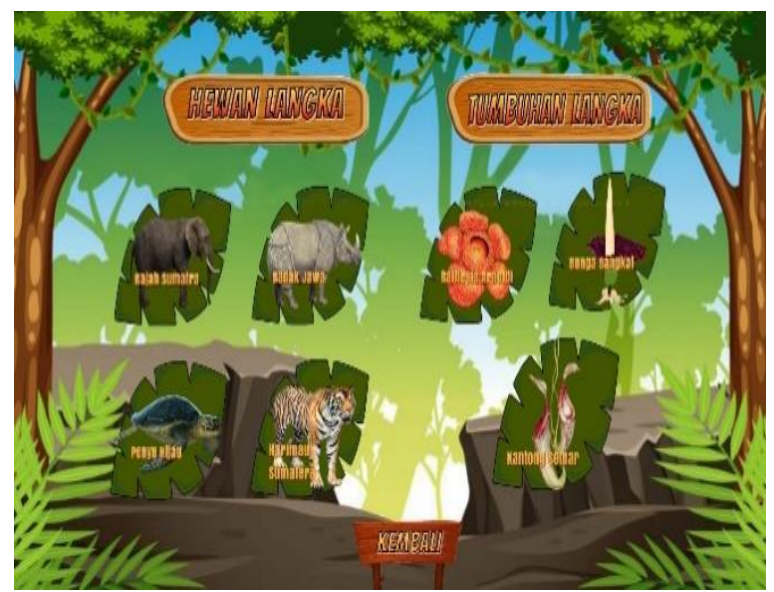

Source : (Darmawel, 2019)

Figure 4. Display of 3D Object Selection

Figure 4. is the display when the user selects the 'AR camera' menu which is a 3D object selection page. Objects that can be seen by users are divided into two, namely endangered animals and plants. The endangered animal's objects consist of the Sumatran Elephant, Javan Rhinoceros, Green Sea Turtle, and Sumatran Tiger. 
Endangered plant objects consist of Rafflesia Arnoldi, Titan Arum, and Tropical Pitcher Plant.

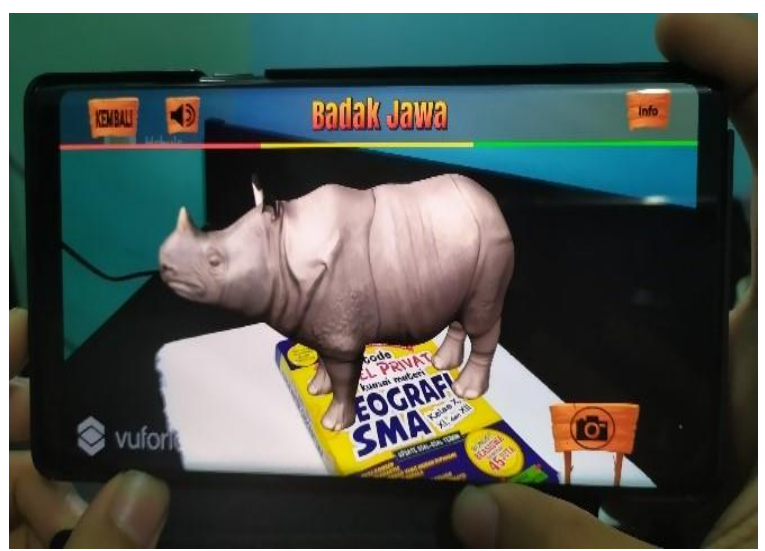

Source : (Darmawel, 2019)

Figure 5. Display of Endangered Animal Javan Rhinoceros AR

Figure 5. is one of the displays of the AR camera, which is the Javan Rhinoceros Object. Objects can appear by using a marker. Users can freely choose and use markers according to the criteria described in the application usage guide on the main menu. Users can use the AR feature by pointing the camera at the marker then pressing the camera button in the lower right corner then the object will appear as shown in Figure 5. In this menu, there is a feature to listen to the sound of an object and an info button to view information according to the selected object.

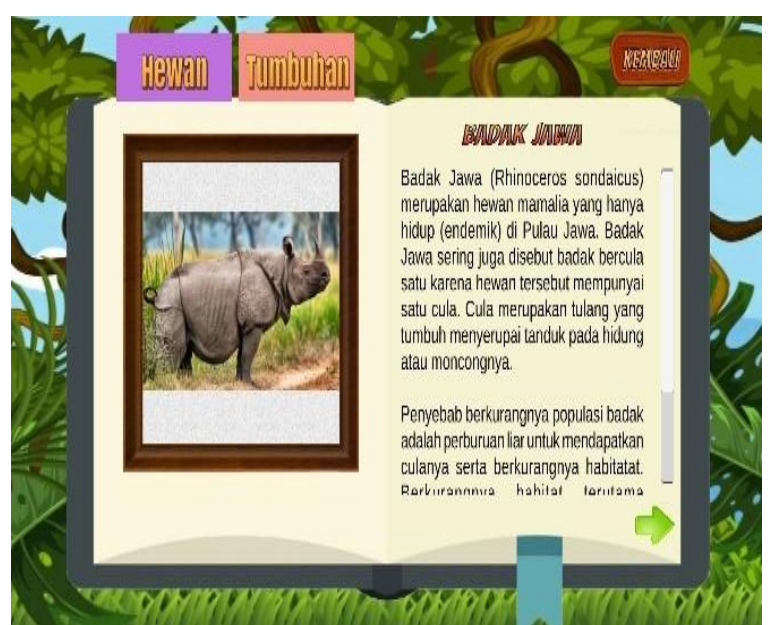

Source : (Darmawel, 2019)

Figure 6. Display of Learning Material

Figure 6 . is the display of the learning material menu. Users can read materials related to endangered animals and plants that are adapted to objects on the AR camera menu. The material in the learning material menu can be read first before the user answers the quiz on the quiz menu.



Source : (Darmawel, 2019)

Figure 7. Display of Quiz

Figure 7. is the display of the quiz menu. Ten questions must be answered by the user. The answer type is a multiple-choice consisting of 4 answer choices. The score can be seen on the upper right side of the page.

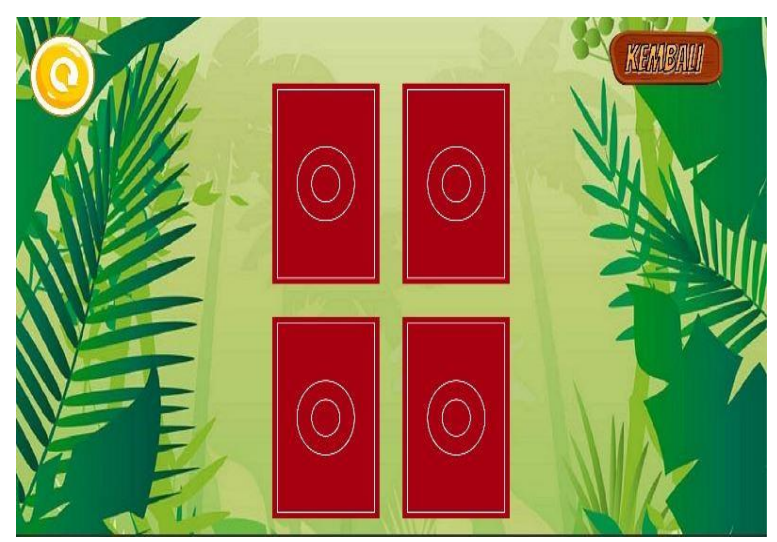

Source : (Darmawel, 2019)

Figure 8. Display of HEBULA Memory Game Level 1

Figure 8. is the display of the game menu. the game is called the HEBULA memory game which is a game to match cards with images of endangered Indonesian animals and plants. There are 5 levels in the HEBULA memory game. Figure 8. is an example of level 1 . The higher the level, the more the number of cards.

\section{User Acceptance Test (UAT)}

At this stage, the respondents carry out the implementation and testing of the application. Respondents were asked to fill out a questionnaire consisting of statements relating to the features contained in the application. The respondents who are elementary school students will fill out a questionnaire after trying the HEBULA Application.

\section{UAT Analysis}

The UAT used a Likert scale as the level of assessment. The questionnaire consists of 10 
statements consisting of display and functional aspects that related to the HEBULA Application. Table 1 . is the UAT questionnaire distributed to respondents. Table 2 . represents the processing results taken from the questionnaire data that has been filled in by the respondent.

Table 1. UAT Questionnaire

\begin{tabular}{|c|c|c|c|c|c|c|}
\hline No & Questions & SA & $\mathbf{A}$ & $\mathbf{N}$ & D & SD \\
\hline \multicolumn{7}{|c|}{ Display } \\
\hline 1 & $\begin{array}{l}\text { The layout of the } \\
\text { buttons in the } \\
\text { application are } \\
\text { arranged according to } \\
\text { their place }\end{array}$ & 6 & 4 & 0 & 0 & 0 \\
\hline 2 & $\begin{array}{l}\text { The texts on the } \\
\text { application can be } \\
\text { seen clearly }\end{array}$ & 8 & 2 & 0 & 0 & 0 \\
\hline 3 & $\begin{array}{l}\text { The display of the } \\
\text { Hebula application is } \\
\text { interesting }\end{array}$ & 5 & 3 & 2 & 0 & 0 \\
\hline 4 & $\begin{array}{l}\text { The menus contained } \\
\text { in the application is } \\
\text { quite complete }\end{array}$ & 5 & 5 & 0 & 0 & 0 \\
\hline 5 & $\begin{array}{l}\text { The features contained } \\
\text { in the application are } \\
\text { interesting }\end{array}$ & 6 & 3 & 1 & 0 & 0 \\
\hline \multicolumn{7}{|c|}{ Functional } \\
\hline 6 & $\begin{array}{l}\text { The buttons contained } \\
\text { in the application } \\
\text { function properly }\end{array}$ & 7 & 2 & 1 & 0 & 0 \\
\hline 7 & $\begin{array}{l}\text { The augmented reality } \\
\text { feature of endangered } \\
\text { animals and plants in } \\
\text { Indonesia helps in the } \\
\text { learning process in } \\
\text { schools }\end{array}$ & 9 & 1 & 0 & 0 & 0 \\
\hline 8 & $\begin{array}{l}\text { The application makes } \\
\text { it easier for users to } \\
\text { learn endangered } \\
\text { animals and plants in } \\
\text { Indonesia }\end{array}$ & 5 & 5 & 0 & 0 & 0 \\
\hline 9 & $\begin{array}{l}\text { The features contained } \\
\text { in the application are } \\
\text { easy to use }\end{array}$ & 8 & 2 & 0 & 0 & 0 \\
\hline 10 & $\begin{array}{l}\text { The performance of } \\
\text { the application } \\
\text { provides a fast } \\
\text { response }\end{array}$ & 8 & 2 & 0 & 0 & 0 \\
\hline
\end{tabular}

Source : (Darmawel, 2019)

Table 2. Results of Questionnaire Data Processing

\begin{tabular}{llllllll}
\hline No & Questions & SA & A & N & D & SD & $\begin{array}{c}\text { TO- } \\
\text { TAL }\end{array}$ \\
\hline Display & & & & & & \\
\hline $1 \quad \begin{array}{l}\text { The layout of } \\
\text { the buttons in } \\
\text { the application } \\
\text { are arranged } \\
\text { according to } \\
\text { their place }\end{array}$ & 6 & 4 & 0 & 0 & 0 & 10 \\
\hline 2 & The texts on & 8 & 2 & 0 & 0 & 0 & 10 \\
\hline
\end{tabular}

\begin{tabular}{|c|c|c|c|c|c|c|c|}
\hline No & Questions & SA & $\mathbf{A}$ & $\mathbf{N}$ & D & SD & $\begin{array}{l}\text { TO- } \\
\text { TAL }\end{array}$ \\
\hline & $\begin{array}{l}\text { the application } \\
\text { can be seen } \\
\text { clearly }\end{array}$ & & & & & & \\
\hline 3 & $\begin{array}{l}\text { The display of } \\
\text { the Hebula } \\
\text { application is } \\
\text { interesting }\end{array}$ & 5 & 3 & 2 & 0 & 0 & 10 \\
\hline 4 & $\begin{array}{l}\text { The menus } \\
\text { contained in } \\
\text { the application } \\
\text { is quite } \\
\text { complete }\end{array}$ & 5 & 5 & 0 & 0 & 0 & 10 \\
\hline 5 & $\begin{array}{l}\text { The features } \\
\text { contained in } \\
\text { the application } \\
\text { are interesting }\end{array}$ & 6 & 3 & 1 & 0 & 0 & 10 \\
\hline \multicolumn{8}{|c|}{ Functional } \\
\hline 6 & $\begin{array}{l}\text { The buttons } \\
\text { contained in } \\
\text { the application } \\
\text { function } \\
\text { properly }\end{array}$ & 7 & 2 & 1 & 0 & 0 & 10 \\
\hline 7 & $\begin{array}{l}\text { The } \\
\text { augmented } \\
\text { reality feature } \\
\text { of endangered } \\
\text { animals and } \\
\text { plants in } \\
\text { Indonesia } \\
\text { helps in the } \\
\text { learning } \\
\text { process in } \\
\text { schools }\end{array}$ & 9 & 1 & 0 & 0 & 0 & 10 \\
\hline 8 & $\begin{array}{l}\text { The } \\
\text { application } \\
\text { makes it } \\
\text { easier for } \\
\text { users to learn } \\
\text { endangered } \\
\text { animals and } \\
\text { plants in } \\
\text { Indonesia }\end{array}$ & 5 & 5 & 0 & 0 & 0 & 10 \\
\hline 9 & $\begin{array}{l}\text { The features } \\
\text { contained in } \\
\text { the application } \\
\text { are easy to use }\end{array}$ & 8 & 2 & 0 & 0 & 0 & 10 \\
\hline 10 & $\begin{array}{l}\text { The } \\
\text { performance } \\
\text { of the } \\
\text { application } \\
\text { provides a fast } \\
\text { response }\end{array}$ & 8 & 2 & 0 & 0 & 0 & 10 \\
\hline & TOTAL & 67 & 29 & 4 & 0 & 0 & 100 \\
\hline
\end{tabular}

Source : (Darmawel, 2019)

The answer to each statement has a different weight value. The following Table 3. is the rating point of each answer: 
Table 3. Rating Point

\begin{tabular}{lc}
\hline \multicolumn{1}{c}{ Agreement } & Point \\
\hline Strongly Disagree & 1 \\
\hline Disagree & 2 \\
\hline Neutral & 3 \\
\hline Agree & 4 \\
\hline Strongly Agree & 5 \\
\hline
\end{tabular}

Source : (Darmawel, 2019)

Based on the results of the questionnaire data processing in Table 2. The following is a description of the calculation of the questionnaire data processing:

1. Strongly Agree, was obtained 67 answers from respondents. The calculation can be shown on the equation below:

Strongly Agree $=67 \times 5=335$ point

2. Agree, was obtained 29 answers from respondents. The calculation can be shown on the equation below:

Agree $=29 \times 4=116$ point

3. Neutral, was obtained 4 answers from respondents. The calculation can be shown on the equation below

Netral $=4 \times 3=12$ poin

4. Disagree and Strongly Disagree, was obtained 0 answers from respondents.

The frequency of data (f) calculations can be shown on the equation below:

$f=\operatorname{Point}(S A)+\operatorname{Point}(A)+\operatorname{Point}(N)+$

Point $(D)+$ Point $(S D)$

$=335+116+12$

$=463$ point

The calculation of the number of samples processed (N) can be shown in the equation below: $N=$ Highest Rating Point $\times$ Total Answers ...(2) $N=5 \times 100=500$

The formula to get the Interval (I) is shown in the equation below:

$$
\begin{aligned}
& I=\frac{100}{\text { Total Score (Likert) }} \\
& I=\frac{100}{5}=20 \%
\end{aligned}
$$

The interval is used to determine the rating scale. The interval used is $20 \%$ starting from the lowest distance of $0 \%$ to the highest of $100 \%$, Table 4 . below is the rating scale used:
Table 4. Interpretation of Score After Conversion

\begin{tabular}{ll}
\hline \multicolumn{1}{c}{ Rate (\%) } & \multicolumn{1}{c}{ Classification } \\
\hline $0-20$ & Very Bad \\
\hline $21-40$ & Bad \\
\hline $41-60$ & Below Average \\
\hline $61-80$ & Good \\
\hline $81-100$ & Excellent \\
\hline Source : (Darmawel, 2019)
\end{tabular}

The calculation for obtaining the percentage of UAT result is shown in the equation below:

Percentage $(\%)=\frac{f}{N} \times 100 \%$

Description:

P : Percentage

$f$ : Data Frequency

N: Number of Samples Processed

$$
\begin{aligned}
\text { Percentage }(\%) & =\frac{463}{500} \times 100 \% \\
& =92,6 \%
\end{aligned}
$$

Based on the results of percentage, it can be conclude from the number of user acceptance test (UAT) which is $92,6 \%$, HEBULA Application can be categorized as "Excellent".

\section{CONCLUSION}

Based on the analysis of usability testing using UAT which consists display and functional, the results show that the HEBULA Application which is an interactive learning media for endangered animals and plants in Indonesia for elementary school children using AR is very suitable for use to understanding learning about endangered animals and plants in Indonesia. This application can increase interest and make it easier for elementary school children to learn about endangered animals and plants in Indonesia.

\section{REFERENCE}

Agustina, R., \& Suprianto, D. (2018). Analisis Hasil Pemanfaatan Media Pembelajaran Interaktif Aljabar Logika Dengan User Acceptance Test (UAT). SMATIKA Jurnal, 8(2), 67-73. Retrieved from http://jurnal.stiki.ac.id/SMATIKA/article/vie $\mathrm{w} / 205$

Darmawel, P. S. (2019). Augmented Reality Application For Introducing Endangered Indonesian Animals And Plants For Elementary School Children Using Android Based User Defined Target Markerless Tracking Method. Gunadarma University. 
Devayana, I. K. D. D. (2017). Pembelajaran Multimedia Interaktif Guru PJOK. Seminar Nasional Pendidikan Olahraga, 422-429. Malang: Universitas Negeri Malang.

Dewi, A. R., Isnanto, R. R., \& Martono, K. T. (2015). Aplikasi Multimedia sebagai Media Pembelajaran Ilmu Pengetahuan Sosial Materi Budaya di Indonesia menggunakan Unity Engine untuk Sekolah Dasar. Jurnal Teknologi Dan Sistem Komputer, 3(4), 471. https://doi.org/10.14710/jtsiskom.3.4.2015. 471-480

Dhiyatmika, I. D. G. W., Putra, I. K. D., \& Mandenni, N. M. I. M. (2015). Aplikasi Augmented Reality Magic Book Pengenalan Binatang untuk Siswa TK. Lontar Komputer, 6(2), 589-596. Retrieved from https://ojs.unud.ac.id/index.php/lontar/artic le/view/16708

Feoh, G., \& Cristyadi, P. M. F. (2018). ANALISA USABILITY TERHADAP PEMBELAJARAN DI SD TEGAL JAYA MENGGUNAKAN AUGMENTED REALITY BERBASIS ANDROID. Seminar Ilmiah Nasional Teknologi, Sains, Dan Sosial Humaniora (SINTESA), (November), 91-100. Bali: LPPM Universitas Dhyana Pura. Retrieved from https://jurnal.undhirabali.ac.id/index.php/si ntesa/article/view/476

Hamidi, N. (2018). Pengembangan Media Pembelajaran Interaktif Pendidikan Agama Islam Berbasis Adobe Flash Professional Cs6 Untuk Mendukung Implementasi Kurikulum 2013. Jurnal Pendidikan Agama Islam, 14(1), 109-130.

https://doi.org/10.14421/jpai.2017.141-07

Hidayat, T., \& Setiyadi, D. (2017). Animasi Pop Up Pengenalan Hewan Beserta Klasifikasinya Kepada Anak Sekolah Dasar Menggunakan Teknologi Augmented Reality. Jurnal STMIK ISTB, 2(4), 65-74. Retrieved from http://www.jurnalpradita.com/index.php/jii /article/view/38

Irfansyah, J. (2017). Media Pembelajaran Pengenalan Hewan Untuk Siswa Sekolah Dasar Menggunakan Augmented Reality Berbasis Android. Journal Information Engineering and Educational Technology, 1(1), 9-17. Retrieved from https://journal.unesa.ac.id/index.php/jieet/a rticle/view/667
Kamiana, A., Made, W. A. K., \& Gede, A. P. (2019). Pengembangan Augmented Reality Book Sebagai Media Pembelajaran Virus Berbasis Android. Kumpulan Artikel Mahasiswa Pendidikan Teknik Informatika (KARMAPATI), 8(2), 165-171. Retrieved from https://ejournal.undiksha.ac.id/index.php/K $\mathrm{P} /$ article/view/18351

Kamphuis, C., Barsom, E., Schijven, M., \& Christoph, N. (2014). Augmented reality in medical education? Perspectives on Medical Education, $3(4)$, 300-311. https://doi.org/10.1007/s40037-013-01077

Kemdikbud. (2017). Selalu Berhemat Energi: Tema 2 Buku Tematik Terpadu Kurikulum 2013 (SD/MI Kelas IV). Jakarta: Pusat Kurikulum dan Perbukuan, Balitbang, Kemendikbud.

Lubis, A., Ritonga, A., Hia, Y., \& Nasution, A. A. (2020). Online Learning Design at Higher Education: An Example from Mathematics Classroom. Journal of Physics: Conference Series, 1462(1), 1-7. Medan: Institute of Physics https://doi.org/10.1088/17426596/1462/1/012004

Sembiring, E. B., Wahyuni, D., \& Anurogo, W. (2018). Multimedia Interaktif Pengenalan Hewan dan Tumbuhan Langka Menggunakan Model Tutorial. Journal of Digital Education, Communication, and Arts, 1(2), 103-112. Retrieved from https://jurnal.polibatam.ac.id/index.php/DE CA/article/view/839

Suraya, K. R. (2014). Pembelajaran Tematik Integratif dan Pengaruhnya Terhadap Akhlak Siswa Kelas 4 SD Negeri Cebongan Sleman Yogyakarta Tahun Pelajaran 2013/2014 (Universitas Islam Negeri Sunan Kalijaga Yogyakarta). Universitas Islam Negeri Sunan Kalijaga Yogyakarta. Retrieved from http://digilib.uin-suka.ac.id/13550/1/BAB I\%2C IV\%2C DAFTAR PUSTAKA.pdf

Sutisna, H., \& Hikmah, A. B. (2018). Pemanfaatan Teknologi Adobe Flash dan MDLC untuk Animasi Pengenalan Pakaian Tradisional Indonesia. Jurnal Teknik Informatika, 6(1), 21-30. Retrieved from http://jurnal.stmikdci.ac.id/index.php/jutekin/article/view/19 7

Thomas, R., Linder, K. E., Harper, N., Blyth, W., \& 
Yee, V. (2019). Current and Future Uses of Augmented Reality in Higher Education. Retrieved from IDEA windows.net website: https://ideacontent.blob.core.windows.net/c ontent/sites/2/2019/09/IDEA_Paper_81_1.p df

Wibowo, S. (2012). Media Pembelajaran Persamaan Kuadrat dan Fungsi Kuadrat Mata Pelajaran Matematika Kelas X. Techno.COM, 11(1), 28-36. Retrieved from http://publikasi.dinus.ac.id/index.php/techn oc/article/view/937 